\title{
'Environmental governance' and 'ecosystem management': avenues for synergies between two approaches
}

\author{
Sara Söderström, Kristine Kern, Magnus Broström and Michael Gilek \\ Journal Article
}

\section{Tweet}

N.B.: When citing this work, cite the original article.

Original Publication:

Sara Söderström, Kristine Kern, Magnus Broström and Michael Gilek, 'Environmental governance' and 'ecosystem management': avenues for synergies between two approaches, Interdisciplinary Environmental Review, 2016. 17(1), pp.1-19.

http://dx.doi.org/10.1504/IER.2016.074871

Copyright: Inderscience

http://www.inderscience.com/

Postprint available at: Linköping University Electronic Press

http://urn.kb.se/resolve?urn=urn:nbn:se:liu:diva-133973

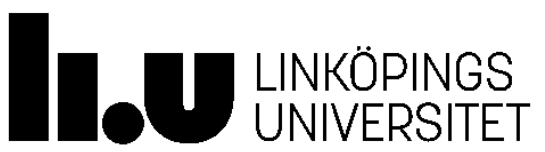




\title{
'Environmental Governance’ and 'Ecosystem Management':
}

\author{
Avenues for Synergies between Two Approaches
}

\section{SARA SÖDERSTRÖM *, KRISTINE KERN **, MAGNUS BOSTRÖM † \& MICHAEL GILEK *}

*School of Natural Sciences, Technology and Environmental Studies, Södertörn University, Huddinge, Sweden.

**Leibniz Institute for Regional Development and Structural Planning \& University of Potsdam, Erkner, Germany

†School of Humanities, Education and Social Sciences, Örebro University, Örebro, Sweden

Corresponding author:

Sara Söderström, Södertörn University, School of Natural Sciences, Technology and Environmental Studies, 14189, Huddinge, Sweden. Fax: + 46 (0)8 6084510 Tel: +46 (0)8 6084567 Email: sara.soderstrom@sh.se

Kristine Kern, Leibniz Institute for Regional Development and Structural Planning (IRS), Flakenstraße 28-31, 15537 Erkner, Germany. Tel: +49 3362793205 Email: kristine.kern@uni-potsdam.de \& kernk@irs-net.de Magnus Boström, Örebro University, School of Humanities, Education and Social Sciences, 70182 Örebro, Sweden. Tel: +46 (0) 19301247 Email: magnus.bostrom@oru.se

Michael Gilek, Södertörn University, School of Natural Sciences, Technology and Environmental Studies, 14189 Huddinge, Sweden. Tel: +46 (0)8 6084862 Email: michael.gilek@sh.se 


\section{Authors bionotes:}

\section{Sara Söderström}

Sara Söderström is a $\mathrm{PhD}$ candidate at Södertörn University, Sweden. Her research interest rests within regional environmental governance having the Baltic Sea as a focal point, aligned with an emphasis on the ecosystem approach to management.

\section{Kristine Kern}

Kristine Kern is professor in 'Governance of Urban Infrastructure and Global Change', University of Potsdam and Leibniz Institute for Regional Development and Structural Planning (IRS). Her current research interests are in the areas of local and regional climate and energy policy, sustainable development of cities and regions, transnational networks of cities, European regional seas (Baltic Sea in particular) and the EU macro-regional strategies.

\section{Magnus Boström}

Magnus Boström is professor in sociology at Örebro University, Sweden. He focus on the intersection between environment, politics and organization. His research and teaching interest generally concern politics, governance, participation, communication, organization, and responsibility in relation to transnational environmental and sustainability issues. Boström is also studying how various factors shape green consumerism and organized activism.

\section{Michael Gilek}

Michael Gilek is Associate Professor in Ecology/Ecotoxicology at Södertörn University and has extensive research experience on chemical pollution and other ecological risks in the aquatic environment, as well as on associated science-policy interactions. In his current research MG leads international interdisciplinary studies analysing marine spatial planning and environmental governance in the Baltic. 


\title{
'Environmental Governance' and 'Ecosystem Management': Avenues for Synergies between two Approaches
}

\begin{abstract}
Based on a literature review of over 160 journal articles and books, this paper examines the ecosystem management and environmental governance approaches, and looks for common topics and integrated research agendas. While scientific articles on environmental governance stem primarily from social science research, the ecosystem management approach is more natural-science-oriented. A review of journal articles from the ISI Web of Knowledge (Web of Science) reveals that the two research communities hardly interact. The paper discusses two thematic linkages between the two approaches: the debates dealing with the scale and level of environmental policy; and the discussions surrounding multi-stakeholder participation. Moreover, the article identifies areas with a high potential for the establishment of common ground, such as the current discussion on science-policy interfaces. We argue for more interaction, claim that the two research approaches can learn from each other, and discuss the potential for the development of interdisciplinary research agendas.
\end{abstract}

KEY WORDS: Environmental governance, ecosystem management, scale, level, multistakeholder participation, science-policy interface

\section{Introduction}

Although authors in the environmental sciences often claim that approaches from the natural and social sciences can be combined and that truly interdisciplinary research agendas, theories, and methods can be developed, most interdisciplinary ambitions appear to be more rhetorical than real. Given the long separated scholarly traditions and the dualistic worldviews that prevail within these disciplines, the development of integrated research agendas and common conceptual frameworks is arguably one of the most difficult tasks facing current academic life.

This article looks for traditions from 'each camp' that may share research agendas, topics, and arguments. The concepts of 'ecosystem management' and 'environmental governance' represent interesting areas in this respect, since they display apparent similarities despite their separate origins, and because both are well established within academia. The former originates from natural-scientific research fields, such as conservation biology, while the latter has developed from social science studies in the areas of globalization, international politics, comparative politics, and public administration. Although exchange between these two approaches has been very limited, existing linkages may provide a basis for the combination and integration of these approaches and an improved understanding of socio-ecological systems.

It has to be noted that both approaches are not static but have progressed for a number of years and are still in flux. Within governance theory there appears to be very little agreement on what the term actually stands for, and the same uncertainties exist in relation to ecosystem management (Evans, 2012; Garcia, 2003; Wang, 2004; Yaffee, 1999). Although these differences and internal variations constrain the development of integrative approaches, the search for similarities and common topics and in which common ground has already been established, appear to constitute a promising agenda. 
Based on a literature review as well as a database analysis on ecosystem management and environmental governance, the aim of this article is threefold: first, to describe how these two fields of academic enquiry have developed over time and how they interrelate to each other. Second, to discuss thematic linkages in relation to (i) the debates dealing with the scale and level of environmental problems and environmental policy and (ii) the discussions on partnerships and multi-stakeholder participation. Third, to identify trends towards convergence of the two approaches and areas with a high potential for identification of common ground and development of interdisciplinary research agendas.

\section{The Concepts of 'Ecosystem Management' and 'Environmental Governance': a Review}

Based on a literature review on more than 160 academic papers and books within the two strains of research, the following section provides a short overview of the concepts of ecosystem management and environmental governance. The aim is to introduce both approaches, describe the emergence and development of these schools, indicate their key topics and characteristics, and draw some conclusions concerning their current status.

\subsection{Ecosystem Management}

In contrast to traditional resource management, where the main objective is to optimize sustainable exploitation of resources such as fish and forests, Ecosystem Management (EM) embraces a broader view by combining human activities with the preservation of entire ecosystems (Grumbine, 1997). Thus, the approach strives to consider not only the sustainability of the exploited resource but also the sustainability of other indirectly affected ecosystem components as well as ecosystem function and services. The holistic approach can be traced as far back as the 1930s. The first publications on ecosystem management appeared in the 1970s, and some prominent work was published in the 1970s and 1980s (Grumbine, 1994). Since then the number of publications has increased steadily. Ecosystem management has been applied to different areas of research, such as marine environment, fisheries, forest management, and the urban environment. Analyses generally focus on local ecosystems and ecological regions. In the US, where ecosystem management has been under development since the early 1990s, several federal and state agencies strive to implement suitable versions of ecosystem management as a guiding policy (Pavlikakis \& Tsihrintzis, 2000). (For the U.S. see also (McMahon et al., 2001; Omernik, 2004).

Various authors have discussed the key characteristics of ecosystem management, focusing on topics such as boundaries and the scale of ecosystems, collected type of data and indicators, organizational change such as interagency cooperation and collaborative stewardship, stakeholder influence and public involvement including collaborative learning efforts between professionals, scientists, and the public (Berkes, Armitage, \& Doubleday, 2007; Brussard, Reed, \& Tracy, 1998; Endter-Wada, Blahna, Krannich, \& Brunson, 1998; Grumbine, 1994; Keough \& Blahna, 2006). However, opinions on ecosystem management vary considerably and implementation problems are ubiquitous (Lackey, 1998). Both the terms 'ecosystem' and 'management' lacks clear definitions (Wang, 2004). Moreover, there is no agreed upon definition of 'ecosystem management', and the term itself is subjected to a long range of variations, where ecosystem-based management, integrated ecosystem management or total ecosystem management are just a few (Wang, 2004). Fundamental to this discussion is the 'ecosystem approach', gaining providence since the establishment of the Convention on 
Biological Diversity (CBD) 1992. The ecosystem approach comprise a set of principles for the management of natural resources and in the fifth Conference of the Parties of the CBD the ecosystem approach was described as "a strategy for the integrated management of land, water and living resources that promotes conservation and sustainable use in an equitable way", "[...]based on the application of appropriate scientific methodologies focused on levels of biological organization, which encompass the essential structure, processes, functions and interactions among organisms and their environment. It recognizes that humans, with their cultural diversity, are an integral component of many ecosystems" (COP V Decision VI6, 2000). The principles of the ecosystem approach are applied within ecosystem management. However, as with ecosystem management there is no clear definition of the ecosystem approach. There are also several expressions, such as ecosystem-based approach, ecosystem management approach, ecosystem process-oriented approach etc (Wang, 2004). Nevertheless, the core of the ecosystem approach as well as ecosystem management is reasonably consistent, and despite the parallel terminology the use of 'ecosystem management' is most common when it comes to the management of natural resources through principles of the ecosystem approach. Or, as described by Slocombe 1998: Ecosystem management is best thought of as short hand for "the process of ecosystem-based management of human activities" (Slocombe, 1998).p 483.

The core characteristics of ecosystem management is the inclusion of the human element and an acceptance of societal utilization of the ecosystem and its services, emphasizing multipleuse and intergenerational sustainability, and acknowledging the importance of high quality science (Pavlikakis \& Tsihrintzis, 2000). A second topic is the integration of stakeholders and the public in decision-making, incorporating concepts such as collaboration, partnerships, and public involvement (Colding, Lundberg, \& Folke, 2006; Endter-Wada et al., 1998; Grumbine, 1997; Jentoft, van Son, \& Bjørkan, 2007; Keough \& Blahna, 2006; Lubell, 2004; Parr, Sier, Battarbee, Mackay, \& Burgess, 2003). Roe and van Eeten (2001) highlight a third element of the current debate, the importance of learning, which they describe as an "incremental and interactive process of experimentation, re-experimentation, continuous hypothesis testing, with feedback and trial-and-error knowledge generation, all guiding management redesign and implementation."(Roe \& Van Eeten, 2001, p. 195). A fourth topic, which refers to both stakeholder participation and learning, is the debate on adaptive (co-)management. The ecosystem management approach can be regarded as a paradigm shift from linear resource management to adaptive management, which takes uncertainty explicitly into account (Brussard et al., 1998; Bunch, McCarthy, \& Waltner-Toews, 2008). Stakeholder communication, the responsiveness to evolving goals and new knowledge, learning from experience, and learning cycles are essential elements for the development of adaptive management (Bunch, 2003).

Summing up, ecosystem management is in part a normative concept, often covering a specific area with an explicitly developed management plan, aiming at the management of socioecological systems with a long-term focus and part of an overall sustainable development agenda. Turning to environmental governance, this is somewhat broader and less place-based approach, hence offering an important complement to ecosystem management.

\subsection{Environmental Governance}

Over the past 15 years, we have witnessed an increasing interest in governance in a variety of literatures, including on international relations, globalization, comparative politics, and environmental policy-making. The popularity of this concept indicates a strong demand for a better understanding of the multifaceted ways in how modern societies are governed. Social 
and political systems are becoming more complex, globalized and differentiated it is claimed, and the boundaries between societal spheres - state, market and civil society - are increasingly blurred.

Governance scholars observe that we live in a polycentric world with multiple sources of authority where states are compelled to develop new forms of regulation in collaboration with actors in the surrounding society (Djelic \& Sahlin-Andersson, 2006; Hall \& Biersteker, 2002; Karkkainen, 2004; Rosenau \& Czempiel, 1992; Rosenau, 2003). The common phrase 'governance without government' (Kaika \& Page, 2003; Pierre \& Peters, 2000; Rhodes, 1997; Rosenau \& Czempiel, 1992) indicates that political institutions no longer exercise a monopoly in the governing of societies. However, while some refer to the hollowing out of the state, others claim that we are witnessing a transformation of the state rather than its decline. This transformation leads to new governance arrangements which involve the transfer of national authority in three directions: upward to the level of international and supranational institutions, sideways to civil society actors, and downward to subnational actors (Pierre \& Peters, 2000; Rosenau, 1999). However, governance could be understood in different ways, with a focus either on structures, processes, systems, networks, management, regulation, or a combination of these and other concepts (Pierre \& Peters, 2000).

However, a core concept tends to denote both structures and processes for collective decisionmaking and collaboration including both state and non-state actors at different levels - i.e. local, regional, national, and global. Hence, governance is a multi-actor and multi-level phenomenon and involves both vertical and horizontal steering, regulation and interaction. Furthermore, governance denotes structures and processes, where power, authority, and responsibility are distributed among both public and private actors, and is hence difficult to locate. Environmental risks and hazards dramatize and reveal nation-state incapacity and the urgent need to develop new forms of inter-, supra-, and transnational collaboration and governing. Hence, the popularity of the concept of 'environmental governance' (and similar terms such as 'governance for sustainable development') has been growing. Environmental governance accordingly pays attention to collective decision-making on the environment as a multi-actor and multi-level process, and new ways of regulation and collaboration in an increasingly complex, risky, globalized, and less state-centric world Author ${ }^{2}$, 2007, (Bäckstrand, 2006; Chasek, Downie, \& Welsh Brown, 2006; Durant, Fiorino, \& O'Leary, 2004; Glasbergen, Biermann, \& Mol, 2007; Joas et.al., 2007; Karkkainen, 2004; Lafferty \& Meadowcroft, 1996; Speth \& Haas, 2006).

Lemos and Agrawal (2006) describes environmental governance as "interventions aiming at changes in environmental-related incentives, knowledge, institutions, decision making and behaviors" and "a set of regulatory processes, mechanisms and organizations through which political actors influence environmental actions and outcomes" (Lemos \& Agrawal, 2006, p. 298). Environmental governance thus covers political-economic relationships, market-based mechanisms and self-regulatory processes (Lemos \& Agrawal, 2006). Evans (2012) discusses "environmental issues as a crisis of governance, or a failure to organize our societies and economies in such a way that they do not harm the environment" (Evans, 2012, p 1), where it is argued that the scientific and technological knowledge and solutions to environmental problems may exist but are not enough if the political system and collective action lacks initiative or appropriate governance (Evans, 2012). Governance is situated as a third alternative of reaching (societal) common goals through steering processes, between the market and the state, with a broad inclusion of stakeholders such as NGOs, business, charities or the public whom collectively formulate the appropriate way to reach the desired targets in various issues (Evans, 2012). Or, as discussed by Young (2008), governance is seen as an umbrella covering multiple actors where the 'government' may be one of them, and where governance is described 
as: “... a social function centered on efforts to steer or guide societies toward collectively beneficial outcomes and away from outcomes that are collectively harmful [...]" (Young, 2009, p 12). According to Elliot (2004), the realm of environmental governance has been filled with various institutional structures since the early 1970s. More or less informal and dealing with negotiation, standard-setting and global change, these institutions include several actors such as issue-specific secretariats and many organizations and associations (Elliott, 2004). We now witness such gradual institutionalization in, for example, marine governance, forest governance, food governance, climate governance, and natural resource governance (Haas, 2004; Oosterveer, 2007; Pattberg, 2007; Pettenger, 2007; Sikor, 2008).

\subsection{Development Over Time}

To attain a better picture of how ecosystem management and environmental governance have developed over time we have studied the occurrence of the two terms in scientific articles. This analysis was performed by analyzing the annual occurrence of the phrases 'environmental governance' and 'ecosystem management', and the combination of the two within the database ISI Web of Knowledge and the Web of Science section (Science Citation Index, SCI, and Social Science Citation Index, SSCI). The Web of Science contains seven databases with information from thousands of scholarly journals, books, book series, reports, conferences, etc. The Web of Science section contains three databases: Science Citation Index Expanded (SCI-Expanded), Social Sciences Citation Index (SSCI) and Arts \& Humanities Citation Index (A\&HCI). The Web of Science is highly renowned and was thus chosen due to its popularity and extensive use among researchers since it is one of the largest academic databases available. Although it does not cover all journals, it is a widely utilized tool and, therefore, mirrors the reality faced by many scientists. Although we fully acknowledge the rapidly increasing number of textbooks, anthologies, and monographs, particularly in the field of environmental governance, this analysis focuses on peer-reviewed articles since this probably is the most diverse body of literature on this topic.

The performed article searches revealed that, while the term 'ecosystem management' emerged as far back as the mid-1970s, 'environmental governance' is a more recent topic; the first article on this subject was published in 1990. Since then the use of both terms has increased gradually. Furthermore, a comparison of hits in Web of Science (SCI and SSCI) show that 'environmental governance' is more prominent in the social sciences (SSCI) and 'ecosystem management' dominates in the natural sciences (SCI). However, overlaps exist where the papers are placed both within the SSCI as well as SCI due to publication in multidisciplinary journals, categorized in both indexes, showing a multidisciplinary tendency when publishing research within these fields. A closer look at specific journals within both the social and natural sciences published in recent years reveal the separate use of the terms. Within the timeline 1990-2013, only twelve articles can be found that in some respect refer to the two concepts. In some publications both phrases were found only in the abstract, as key words, in the reference list, or briefly mentioned as part of previous research. In the end only a handful of papers were actually mentioning or discussing one or both of the concepts in the actual text.

Our analysis shows that: (i) the ecosystem management approach has significantly more publications- due to its earlier development; (ii) the concept of environmental governance is not commonly used in natural science; (iii) there is a multidisciplinary tendency when publishing research within these fields, where an index overlap exists since some papers are 
placed in both the SCI and SSCI due to publications in multidisciplinary journals; (iv) integrated approaches are still largely lacking.

Table 1. The annually occurrence of the phrases "environmental governance" and "ecosystem management" between the year 1975 to 2014

\begin{tabular}{|c|c|c|c|c|c|c|c|c|c|}
\hline Year & Env gov & Eco man & Cross ref & EG SCI & EG SSCI & Overlap EG & EM SCI & EM SSCI & Overlap EM \\
\hline 1975 & - & - & - & - & - & - & - & - & - \\
\hline 1976 & - & 1 & - & - & - & - & 1 & 1 & 1 \\
\hline 1977 & - & - & - & - & - & - & - & - & - \\
\hline 1978 & - & 2 & - & - & - & - & 2 & 1 & 1 \\
\hline 1979 & - & 2 & - & - & - & - & 2 & 1 & 1 \\
\hline 1980 & - & 3 & - & - & - & - & 2 & 1 & - \\
\hline 1981 & - & - & - & - & - & - & - & - & - \\
\hline 1982 & - & - & - & - & - & - & - & - & - \\
\hline 1983 & - & 4 & - & - & - & - & 4 & 1 & 1 \\
\hline 1984 & - & 1 & - & - & - & - & 1 & 0 & 0 \\
\hline 1985 & - & - & - & - & - & - & - & - & - \\
\hline 1986 & - & - & - & - & - & - & - & - & - \\
\hline 1987 & - & - & - & - & - & - & - & - & - \\
\hline 1988 & - & - & - & - & - & - & - & - & - \\
\hline 1989 & - & 2 & - & - & - & - & 1 & 1 & 0 \\
\hline 1990 & 1 & 3 & - & 1 & 1 & 1 & 2 & 1 & 0 \\
\hline 1991 & 2 & 7 & - & 0 & 2 & - & 6 & 1 & 0 \\
\hline 1992 & - & 8 & - & - & - & - & 8 & 0 & 0 \\
\hline 1993 & 1 & 14 & - & 1 & 0 & - & 8 & 6 & 0 \\
\hline 1994 & 1 & 38 & - & 1 & 0 & - & 33 & 9 & 4 \\
\hline 1995 & 1 & 54 & - & 1 & 0 & - & 50 & 7 & 3 \\
\hline 1996 & 4 & 102 & - & 1 & 3 & - & 90 & 19 & 7 \\
\hline 1997 & 10 & 90 & - & 1 & 9 & - & 72 & 21 & 3 \\
\hline 1998 & 3 & 116 & - & 1 & 2 & - & 83 & 48 & 15 \\
\hline 1999 & 14 & 128 & - & 1 & 13 & - & 108 & 35 & 15 \\
\hline 2000 & 15 & 129 & - & 4 & 12 & 1 & 110 & 35 & 16 \\
\hline 2001 & 10 & 142 & 1 & 3 & 8 & 1 & 128 & 42 & 28 \\
\hline 2002 & 14 & 122 & - & 4 & 12 & 2 & 102 & 31 & 11 \\
\hline 2003 & 26 & 127 & 1 & 9 & 21 & 4 & 108 & 42 & 23 \\
\hline 2004 & 34 & 112 & - & 9 & 27 & 2 & 96 & 29 & 13 \\
\hline 2005 & 36 & 118 & 1 & 5 & 34 & 3 & 107 & 27 & 16 \\
\hline 2006 & 55 & 141 & 2 & 9 & 53 & 7 & 126 & 43 & 28 \\
\hline 2007 & 44 & 159 & - & 8 & 43 & 7 & 129 & 45 & 15 \\
\hline 2008 & 95 & 183 & 1 & 18 & 92 & 15 & 159 & 53 & 29 \\
\hline 2009 & 92 & 152 & 2 & 30 & 85 & 23 & 140 & 41 & 29 \\
\hline 2010 & 121 & 185 & - & 33 & 116 & 28 & 167 & 61 & 43 \\
\hline 2011 & 104 & 168 & 1 & 35 & 99 & 30 & 152 & 56 & 40 \\
\hline 2012 & 189 & 164 & 1 & 54 & 183 & 48 & 149 & 47 & 32 \\
\hline 2013 & 205 & 223 & 2 & 72 & 198 & 65 & 202 & 72 & 51 \\
\hline 2014 & 189 & 185 & 2 & 61 & 182 & 54 & 166 & 56 & 37 \\
\hline sum & 1266 & 2885 & 14 & 362 & 1195 & 291 & 2514 & 833 & 462 \\
\hline
\end{tabular}

Table 1. The annually occurrence of the phrases "environmental governance" and "ecosystem management" between the year 1975 to 2013, as "TOPIC” within the Web of Science 'Science Index' (SCI) and 'Social Science Index' (SSCI), with cross references (both environmental governance and ecosystem management is found in the same paper) and overlap (where a paper is placed in both indexes due to publications in multidisciplinary journals). 


\section{Thematic Affinities Between the Two Approaches}

There are various debates playing a prominent role in both the ecosystem management and environmental governance approaches. An important overlap in both research communities is the discussion on multi-stakeholder arrangements. Another theme of great concern for both approaches is the multi-level and multi-scalar character of ecosystems, social systems, and political systems.

\subsection{Scales and Levels}

Although ecosystem management and environmental governance are focusing on similar topics different terminologies are often used. While the term 'scale' is well established in the ecosystem approach, term 'level' is more common in the (environmental) governance debate. Scale is broader and includes several dimensions, in particular spatial and temporal dimensions, while levels can be regarded as points along a scale, and scaling can be defined as the act of moving up or down from one level to another on a particular scale (Cash et al., 2006; Gupta, 2008).

\subsubsection{Scales and Levels in the Ecosystem Management Approach}

While traditional ecology has often focused on small scales, ecosystem management takes large scales into account, and embraces broader perspectives, which are offered, for example, by systems, landscape, and conservation ecology (Brussard et al., 1998). In particular the shift of focus from sustainable exploitation of particular natural resources towards sustainable management of ecosystems with all their complexity and interdependencies among species and components has inevitably led to a more large-scale approach. The scope of ecosystem management has developed to address evolving large-scale environmental challenges posed by, for example, biodiversity loss, chemical pollution, and climate change. The debate on subglobal assessments (as part of the Millennium Ecosystem Assessment) and on the definition of ecological regions (eco-regions), which aim to facilitate effective implementation of ecosystem management at different levels, demonstrates this general trend from smaller to larger scales.

A contentious topic is the boundaries of ecosystems. As ecosystems are dynamic and seldom display defined borders or boundaries, they may have impacts on each other's processes. Thus, it may be difficult to choose a suitable scale and boundary of ecosystem management units (Brussard et al., 1998). This debate points to the need to take the relations and interactions of scales and levels into account. Therefore, the hierarchical context of scales has become a major theme within the ecosystem management approach. Grumbine (1994) stresses that the focus at one level of the biodiversity hierarchy (consisting of genes, species, populations, ecosystem, and landscapes) is not enough. "When working on a problem at any one level or scale, managers must seek the connections between all levels.” (Grumbine, 1994, p.29). Although ecosystem management can be effective at population, community, regional, and landscape scale, it is important to note that changes at one scale may impact the others. As adaptive management approaches emphasize the relevance of ecosystems as highly dynamic and complex systems, they may be useful in building a theory of cross-scale institutional linkages (Berkes, 2002; Grumbine, 1997). "Although much focus is still on the local scale, where issues of management performance are felt most directly, adaptive co-management is a flexible system for environment and resource management that operates across multiple levels and with a range of local and non-local organizations" (Berkes et al., 2007, p. 5).

In sum, there has been a development towards addressing environmental issues at more complex and dynamic scales of ecological organization at larger/longer scales of space and 
time, and towards understanding multi-scale interactions and responses in ecosystems. Links and mismatches between these multi-scale responses and socio-political scales of (adaptive) management have also been at the core of the developing research field.

\subsubsection{Scales and Levels in the Environmental Governance Approach}

In contrast with the ecosystem management approach, which developed from smaller to larger scales, global perspectives and the analysis of international institutions were an essential part of the environmental governance approach from the outset. Many studies are rooted theoretically in the field of international relations and focus empirically on global environmental problems, such as ozone depletion and climate change. The concept of governance has emerged partly as an attempt to understand issues of scale better and to acknowledge the dynamics of multi-level systems. Research on global and international environmental governance still dominates this research field (Axelrod, Downie, \& Vig, 2005; Biermann, Pattberg, Van Asselt, \& Zelli, 2009; Chasek et al., 2006; Park, Conca, \& Finger, 2008; Speth \& Haas, 2006; Young, 2009) and many studies tend to start from a top-down rather than bottom-up perspective.

The 'multi-level governance' approach was developed to grasp the multi-level structures and dynamics of the EU's political system. This concept describes the European Union as a system with multiple levels or spheres of governance, including not only European and national, but also subnational policy arenas (Bache, 2008; Bache \& Flinders, 2004; Hooghe \& Marks, 2003; Winter, 2006). From a multi-level governance perspective the levels of governance are not considered as parts of a stable hierarchical structure. Instead, multi-level governance approaches assume that competencies of governmental institutions are shifted upwards to the European Union and downwards to regions and cities (Pierre \& Peters, 2000; Rosamund, 2007; Rosenau, 2003). Even though multi-level governance emerged as part of EU studies, and still holds a strong normative stand within EU policy, the approach has developed further to include even other areas where the 'multi-level' part of the governance perspective per se needs to be emphasized.

The debate on multi-level governance has shown that the top-down and bottom-up processes, as well as vertical and horizontal interaction (Lafferty \& Hovden, 2003; Selin \& VanDeveer, 2003), need to be integrated if we want to govern the dynamics of multilevel systems and the complex interactions between different levels. This is evident in the literature on the growing importance of subnational governments (Baker \& Eckerberg, 2008; Flynn, 2000; Gibbs, Jonas, \& While, 2002). However, the strong emphasis on multi-level and social arrangements often lack the insights from ecosystem management and the realm of the ecological system, or, as described by Evans (2012): "One of the biggest challenges facing environmental governance involves overcoming the mismatch between political and ecological scales.” (Evans, 2012, p. 59).

\subsection{Multi-Stakeholder Arrangements and Partnerships}

A strong and recurrent emphasis on the inclusion of all relevant actors in policy-making, regulation, and management can be found in both ecosystem management and environmental governance approaches. In addition to the concept 'multi-stakeholder'(see Boström 2014, forthcoming, for a review), Various concepts have been developed to describe and analyze the inclusiveness of decision-making approaches, including: Partnerships (Bäckstrand, 2006; Colding et al., 2006; Glasbergen et al., 2007; Grumbine, 1997; Parr et al., 2003; Sanwal, 2007; von Malmborg, 2003), Collaboration and cooperation (Endter-Wada et al., 1998; Glasbergen, 2002; Grumbine, 1997; Haas, 2000; Hahn, Olsson, Folke, \& Johansson, 2006; Joas et al., 2007; 
Keough \& Blahna, 2006; Lubell, 2004; Oberthür \& Gehring, 2004; Sanwal, 2004), Public involvement and local participation (Bäckstrand \& Lövbrand, 2006; Glasbergen, 2002; Keough \& Blahna, 2006; Parr et al., 2003), Adaptive co-management (Berkes, 2004; Berkes et al., 2007; Endter-Wada et al., 1998; Grumbine, 1994; Grumbine, 1997; Hahn et al., 2006; Keough \& Blahna, 2006; Olsson, Folke, \& Berkes, 2004; Roe \& Van Eeten, 2001; Stringer et al., 2006).

\subsubsection{Multi-Stakeholder Arrangements in the Ecosystem Management Approach}

Cooperation and public-private partnerships have become cornerstones of ecosystem management, covering concepts such as public involvement, collaborative learning, local decision-making partnerships, and co-management (Endter-Wada et al., 1998; Grumbine, 1994; Grumbine, 1997). Public involvement is an important tool in the goal-setting process for the creation of a socio-political climate in support of ecosystem management. In addition, data derived from public involvement processes may help to clarify the conflicting goals of resource managers or government decision makers (Endter-Wada et al., 1998).

Another recurrent topic in the literature is the need for a collaborative approach to the balancing of social, economic, and ecological sustainability objectives and concerns (Endter-Wada et al., 1998; Keough \& Blahna, 2006), and for generating knowledge, stimulating learning, and facilitating capacity-building in ecosystem management (Colding et al., 2006; Endter-Wada et al., 1998; Grumbine, 1997; Hahn et al., 2006; Keough \& Blahna, 2006; Olsson et al., 2004). These scholars often refer to the concept of adaptive co-management, which emphasizes the need to foster a flexible learning environment. Adaptive co-management promotes an incremental and interactive process with feedback, monitoring, and trial-and-error based knowledge generation. Such continuous testing and learning-by-doing is maintained to be a most useful way of coping with socio-ecological complexities, where scholars furthermore argue for the need of considering community-based local knowledge about natural resources. Such local knowledge is often gained from the intensive daily practical interaction with natural resources over long periods of time, and it is stored in the 'social memories' of communities. Hence, there is a need for the broad inclusion of knowledgeable actors in management as well as the fostering of information-sharing in horizontal social networks. Local residents, users, and NGOs can also successfully take part in the monitoring of eco-systems as they may be more sensitive to small variations than scientists: "Local residents can provide early warnings of environmental change” (Olsson et al., 2004, p.85).

\subsubsection{Multi-stakeholder Arrangements in the Environmental Governance Approach}

While the ecosystem management literature tends to focus on collaboration at local levels in close connection with concrete ecosystems, the environmental governance literature tends to discuss the multi-stakeholder topic more broadly from the global to the local level. Positive undertones are common, where scholars tend to assume that many positive synergies, such as increasing social and environmental responsibility-taking and generating new knowledge and understandings, will follow from inclusion of actors representing different sectors or societal sub-systems. Like in ecosystem management, governance theorists maintain that it is usually difficult for the members of a single organization or a single discipline to know the most effective and efficient combination of strategies to use when trying to deal with environmental 
problems. On this basis, several scholars argue for more inclusive policymaking (Glasbergen et al., 2007; Lafferty \& Meadowcroft, 1996). Cooperation as such may also lead to the empowerment of participants as well as a sense of 'broad ownership' of a process among them, and such empowerment and ownership may, in turn, facilitate implementation of rules and policies (Bäckstrand, 2006; Boström 2006b; Glasbergen, 2002; Keough \& Blahna, 2006).

However, potential benefits from stakeholder inclusion cannot be taken for granted. Despite optimistic undertones, environmental governance approaches (and some contributions from the ecosystem management literature) present problems and challenges regarding broad inclusion. Some recurrent topics include power imbalances and representation biases, the risk of cooptation or capture of public interests by private, cumbersome decision-making and the risk of stalemate in dialogue and negotiations, communication barriers due to different cultural traditions and accountability deficits of inclusive arrangements (Author ${ }^{3}$, 2006a, Author $^{3}, 2008$, Biermann, Man-san Chan, \& Pattberg, 2007; Cutler, Haufler, \& Porter, 1999; Endter-Wada et al., 1998; Boström \& Garsten 2008; Grumbine, 1997; Olsson et al., 2004; von Malmborg, 2003). Also other governance theorists discuss how fluid and opaque horizontal governance arrangements make it difficult to identify who can be held responsible and answerable for decisions and actions (Boström \& Garsten 2008; Keohane, 2003; Pierre \& Peters, 2000). To sum up, stakeholder involvement is considered an important and vital part in environmental governance since it increases legitimacy and democracy, even though there are obstacles in regard to power imbalances among the stakeholders as well as the distribution of responsibility.

\section{Integrative Approaches and Interdisciplinary Frameworks}

In the following section we discuss areas we expect to have potential for fostering mutual learning, establishing common grounds and developing interdisciplinary research agendas. Ecosystem management is fundamentally a place-based approach focusing on understanding and implementing sustainable management of social-ecological systems over a range of human activities (McLeod \& Leslie, 2009). Environmental governance scholars have on the other hand to a larger extent focused on global, theoretical and general topics. Still, in our review of the scientific literature it is evident that place-based studies of environmental management and governance is a research field, where environmental governance and ecosystem management already appear to have reached some common ground or could engage in fruitful dialogue

A key area in which environmental governance and ecosystem management approaches are converging is the debate on the interface between science and policy, which can be defined as:

"social processes which encompass relations between scientists and other actors in the policy process and which allow for exchange, co-evolution, and joint construction of knowledge with the aim of enriching decision-making” (Van den Hove, 2007).p 815.

Science-policy interfaces are now frequently analyzed in both ecosystem management and environmental governance (Van den Hove, 2007). Although these interfaces involve a range of relations relating to joint construction, exchange and use of knowledge, the most obvious interface is the use of scientific knowledge and arguments in policy making. Science is an important ingredient in environmental policy-making by, for example, identifying and assessing emerging environmental threats as well as by generating ideas on how to deal with them (Renn, 2008). However, the role of science, including its relation to other types of policy input, is also a highly contested issue for environmental policy and decision-making (Linke et al 2014; Wilson, 2009). There have furthermore been numerous calls for (and subsequent attempts to development) a science more adapted towards guiding environmental management and sustainable development (Clark, 2007; Robertson \& Hull, 2001). 
An interesting observation when searching for fruitful common grounds is that normative and analytical/descriptive aims of ecosystem management and environmental governance are converging from different directions. Thus, ecosystem management has focused primarily on the complexities and dynamics of the ecosystem and any scientific advice has usually been motivated based on this ecosystem-knowledge (or knowledge of the 'system-to-be-governed') (Jentoft et al., 2007). For example, calls for adaptive (co)-management are often motivated by referring to the (socio)-ecological complexities. Implementing ecosystem management will require organizational change that strengthens the relationship between research and management (Brussard et al., 1998). Environmental governance scholars have, on the other hand, mainly approached studies of the challenges and requirements of science-policy interfaces from an analysis of the complexities of the 'governing' system (sensu Jentoft et al.2007). Interdisciplinary research on production, transfer, communication and application of ecological and social knowledge connected with environmental issues thus appears to be a productive common ground for ecosystem management and environmental governance.

Furthermore, a common research agenda also exists in relation to challenges posed by various types of interpretative and normative ambiguity on science-policy interfaces relating to environmental issues. It is clear that knowledge in most key environmental issues, for example biodiversity loss and climate change are both scientifically uncertain and socially ambiguous. Coping with such uncertainties over science-policy interfaces is thus a main challenge for both ecosystem management and environmental governance.

\section{Conclusions}

Although ecosystem management and environmental governance deal with similar research questions, the exchange between these research communities has been rather limited. When comparing both approaches it is observed that (i) the environmental governance approach is still largely unnoticed by natural scientists, (ii) ecosystem management approaches play an important role in both social science journals and multidisciplinary journals, but is still most prominent within natural science, and (iii) the interaction of the concepts is very limited. Thus, strengthening ties and exchanges between these research communities could be promising steps towards mutual learning, cross-fertilization and interaction.

Ecosystem management and environmental governance start from different assumptions and paradigms, and these paradigmatic differences undoubtedly constrain the development of fruitful dialogue and interdisciplinary frameworks. Broadening the view and integrating the approaches could help in recognizing and addressing underdeveloped areas, which can be found in both approaches. Although the terminology may still differ, trends towards convergence can already be observed in some areas. Recent debates, such as the discussion on adaptive comanagement, incorporate elements of both approaches and can serve as one basis for developing common frameworks and research agendas, if that is sought for, as could discussions on science-policy interfaces and coping with uncertainty.

Environmental governance appears to be a broader research agenda than ecosystem management with its more focused perspective on sustainable management of socio-ecological systems. Ecosystem management could learn from environmental governance in several respects. First, the governance approach starts from the assumption that hierarchical governance has reached its limits. New governance structures and processes can thus be regarded important in relation to management decisions. Second, recent developments towards adaptive comanagement show that the concept of resource management has broadened considerably and now encompasses various concepts of stakeholder involvement and participation. Third, 
although multi-stakeholder arrangements have become a broad debate in ecosystem management, what seems to be missing is the development of such concepts for larger geographical areas. Because the ecosystem management approach often starts at local and regional levels, it is compared to environmental governance not yet well equipped to deal with global governance and global problems. Finally, the ecosystem management approach could learn more about how unpredictable dynamic socio-political processes, including the role of power, trust relations, and political cultures affect conditions for place-based natural resource management.

Environmental governance could on the other hand learn from ecosystem management approaches. First, ecosystem management starts from the assumption that ecosystems are complex and developments are uncertain. This has consequences for environmental governance because policy-making must pay more attention to the complex and largely unpredictable interactions between ecosystems and governance institutions. Governing systems need to become more flexible and innovative to be able to adapt to such unexpected changes. Second, political and administrative territories typically form the point of departure in governance studies. This could mean that environmental governance approaches are confronted with boundary problems, when administrative boarders do not match ecosystem boundaries. Third, most environmental governance debates starts at the global level, de-emphasizing the transformation of intergovernmental relations within nation-states and the changing role of subnational governments. However, in certain areas of research we see an increasing use of the local perspective, such as climate adaptation.

We conclude that there is extensive potential for mutual learning and the development of interdisciplinary research agendas that take the general assumptions of both approaches into account. Ecosystem management and environmental governance approaches already converge in areas such as the debates on multi-stakeholder arrangements and linkages within multi-level systems. Increased cross-fertilization between the two approaches where ecosystem complexity becomes a more integrated part of governance analysis and socio-institutional aspects are made integral to the ecosystem approach to management is most likely a promising path forward. 


\section{References}

Author ${ }^{2}, 2007$

Author ${ }^{4}, 2014$

Axelrod, R. S., 'Downie, D. L., \& Vig, N. J. (2005). The global environment: Institutions, law and policy (2nd ed.). Washington D.C: CQ Press.

Bache, I. (2008). Europeanization and multilevel governance: Cohesion policy in the european union and britain Rowman \& Littlefield Pub Inc.

Bache, I., \& Flinders, M. (Eds.). (2004). Multi-level governance. Oxford: Oxford University Press.

Bäckstrand, K. (2006). Multi-stakeholder partnerships for sustainable development: Rethinking legitimacy, accountability and effectiveness. European Environment, 16(5), 290-306.

Bäckstrand, K., \& Lövbrand, E. (2006). Planting trees to mitigate climate change: Contested discourses of ecological modernization, green governmentality and civic environmentalism. Global Environmental Politics, 6(1), 50-75.

Baker, S., \& Eckerberg, K. (Eds.). (2008). In pursuit of sustainable development: New governance practices at the sub-national level in europe Routledge.

Berkes, F. (2002). Cross-scale institutional linkages: Perspectives from the bottom up. In E. by Ostrom, T. Dietz, N. Dolšak, P. C. Stern, S. Stonich \& E. Weber (Eds.), The drama of the commons (pp. 293-321). Washington, DC: National Academy Press.

Berkes, F. (2004). Rethinking community-based conservation. Conservation Biology, 18(3), 621-630.

Berkes, F., Armitage, D. R., \& Doubleday, N. (2007). Adaptive co-management: Collaboration, learning, and multi-level governance. Vancouver/Toronto: UBC Press.

Biermann, F., Man-san Chan, A. M., \& Pattberg, P. (2007). Multi-stakeholder partnerships for sustainable development: Does the promise hold? In P. Glasbergen, F. Biermann \& A. Mol (Eds.), Partnerships, governance and sustainable development (pp. 239).

Cheltenham/Northhampton: Edward Elgar Publishing. 
Biermann, F., Pattberg, P., Van Asselt, H., \& Zelli, F. (2009). The fragmentation of global governance architectures: A framework for analysis. Global Environmental Politics, $9(4), 14-40$.

Boström, M. (2006a). Establishing credibility: Practising standard-setting ideals in a Swedish seafood-labelling case. Journal of Environmental Policy \& Planning, 8(2), 135-158.

Boström, M. (2006b). Regulatory credibility and authority through inclusiveness: Standardization organizations in cases of eco-labelling. Organization, 13(3), 345-367.

Boström, M. \& Garsten, C. (2008). Organizing transnational accountability Edward Elgar Publishing.

Boström, M. (2014). Sustainable development by the multi-stakeholder model? In T. Fitzpatrick (Ed.), In international handbook on social policy \& the environment Edward Elgar.

Brussard, P. F., Reed, J. M., \& Tracy, C. R. (1998). Ecosystem management: What is it really? Landscape and Urban Planning, 40(1), 9-20.

Bunch, M. J. (2003). Soft systems methodology and the ecosystem approach: A system study of the Cooum river and environs in Chennai, India. Environmental Management, 31(2), 0182-0197.

Bunch, M., McCarthy, D., \& Waltner-Toews, D. (2008). A family of origin for an ecosystem approach to managing for sustainability. The Ecosystem Approach: Complexity, Uncertainty, and Managing for Sustainability.New York: Columbia Univ Pr, , 125-138.

Cash, D. W., Adger, W. N., Berkes, F., Garden, P., Lebel, L., Olsson, P., . . Young, O. (2006). Scale and cross-scale dynamics: Governance and information in a multilevel world. Ecology and Society, 11(2), 8.

Chasek, P., Downie, D. L., \& Welsh Brown, J. (2006). Global environmental politics (4th ed.) Boulder: Westview.

Clark, W. C. (2007). Sustainability science: A room of its own. Proceedings of the National Academy of Sciences of the United States of America, 104(6), 1737-1738.

Colding, J., Lundberg, J., \& Folke, C. (2006). Incorporating green-area user groups in urban ecosystem management. AMBIO: A Journal of the Human Environment, 35(5), 237-244.

COP V Decision V/6. (2000). Fifth meeting of the conference of the parties to the convention on biological diversity Nairobi, Kenya 15 - 26 may 2000. Unpublished manuscript.

Cutler, A. C., Haufler, V., \& Porter, T. (1999). Private authority and international affairs. Suny Press.

Djelic, M., \& Sahlin-Andersson, K. (2006). Transnational governance: Institutional dynamics of regulation Cambridge University Press. 
Durant, R. F., Fiorino, D. J., \& O'Leary, R. (2004). Environmental governance reconsidered: Challenges, choices, and opportunities The MIT Press.

Elliott, L. M. (2004). The global politics of the environment Palgrave Macmillan Houndmills,, UK.

Endter-Wada, J., Blahna, D., Krannich, R., \& Brunson, M. (1998). A framework for understanding social science contributions to ecosystem management. Ecological Applications, 8(3), 891-904.

Evans, J., \& Evans, J. (2012). Environmental governance Routledge New York.

Flynn, B. (2000). Is local truly better? Some reflections on sharing environmental policy between local governments and the EU. European Environment, 10(2), 75-84.

Garcia, S. M. (2003). The ecosystem approach to fisheries: Issues, terminology, principles, institutional foundations, implementation and outlook Food \& Agriculture Org.

Gibbs, D., Jonas, A., \& While, A. (2002). Changing governance structures and the environment: Economy-environment relations at the local and regional scales. Journal of Environmental Policy \& Planning, 4(2), 123-138.

Glasbergen, P. (2002). The green polder model: Institutionalizing multi-stakeholder processes in strategic environmental decision-making. European Environment, 12(6), 303-315.

Glasbergen, P., Biermann, F., \& Mol, A. P. (2007). Partnerships, governance and sustainable development: Reflections on theory and practice Edward Elgar Publishing.

Grumbine, R. E. (1994). What is ecosystem management? Conservation Biology, 8(1), 27-38.

Grumbine, R. E. (1997). Reflections on "What is ecosystem management?”. Conservation Biology, 11(1), 41-47.

Gupta, J. (2008). Global change: Analyzing scale and scaling in environmental governance. Institutions and Environmental Change: Principal Findings, Applications, and Research Frontiers, 225-258.

Haas, P. M. (2000). Prospects for effective marine governance in the NW pacific region. Marine Policy, 24(4), 341-348.

Haas, P. M. (2004). Addressing the global governance deficit. Global Environmental Politics, 4(4), 1-15.

Hahn, T., Olsson, P., Folke, C., \& Johansson, K. (2006). Trust-building, knowledge generation and organizational innovations: The role of a bridging organization for adaptive comanagement of a wetland landscape around kristianstad, sweden. Human Ecology, 34(4), 573-592. 
Hall, R. B., \& Biersteker, T. J. (2002). The emergence of private authority in global governance Cambridge University Press.

Hooghe, L., \& Marks, G. (2003). Unraveling the central state, but how?: Types of multi-level governance. American Political Science Review, 97(2), 233.

Jentoft, S., van Son, T. C., \& Bjørkan, M. (2007). Marine protected areas: A governance system analysis. Human Ecology, 35(5), 611-622.

Joas, M., Kern, K., \& Sandberg, S. (2007). Actors and arenas in hybrid networks: Implications for environmental policymaking in the Baltic Sea region. Ambio, 36(2-3), 237-242.

Kaika, M., \& Page, B. (2003). The EU water framework directive: Part 1. european policymaking and the changing topography of lobbying. European Environment, 13(6), 314327.

Karkkainen, B. C. (2004). Post-sovereign environmental governance. Global Environmental Politics, 4(1), 72-96.

Keohane, R. O. (2003). Global governance and democratic accountability. In D. Held, \& M. Koenig-Archibugi (Eds.), In taming globalization. frontiers of governance (pp. 130). Cambridge: Polity.

Keough, H. L., \& Blahna, D. J. (2006). Achieving integrative, collaborative ecosystem management. Conservation Biology, 20(5), 1373-1382.

Lackey, R. T. (1998). Seven pillars of ecosystem management. Landscape and Urban Planning, 40(1), 21-30.

Lafferty, W. M., \& Meadowcroft, J. (1996). Democracy and the environment: Problems and prospects Edward Elgar Cheltenham.

Lafferty, W., \& Hovden, E. (2003). Environmental policy integration: Towards an analytical framework. Environmental Politics, 12(3), 1-22.

Lemos, M. C., \& Agrawal, A. (2006). Environmental governance. Annu.Rev.Environ.Resour., 31, 297-325.

Linke, S., Gilek, M., Karlsson, M., \& Udovyk, O. (2014). Unravelling science-policy interactions in environmental risk governance of the Baltic Sea: Comparing fisheries and eutrophication. Journal of Risk Research, 17(4), 505-523.

Lubell, M. (2004). Resolving conflict and building cooperation in the national estuary program. Environmental Management, 33(5), 677-691.

McLeod, K., \& Leslie, H. (2009). Ecosystem-based management for the oceans. Washington D.C.: Island Press. 
McMahon, G., Gregonis, S. M., Waltman, S. W., Omernik, J. M., Thorson, T. D., Freeouf, J. A., Keys, J. E. (2001). Developing a spatial framework of common ecological regions for the conterminous united states. Environmental Management, 28(3), 293-316.

Oberthür, S., \& Gehring, T. (2004). Reforming international environmental governance: An institutionalist critique of the proposal for a world environment organisation. International Environmental Agreements, 4(4), 359-381.

Olsson, P., Folke, C., \& Berkes, F. (2004). Adaptive comanagement for building resilience in social-ecological systems. Environmental Management, 34(1), 75-90.

Omernik, J. M. (2004). Perspectives on the nature and definition of ecological regions. Environmental Management, 34(1), S27-S38.

Oosterveer, P. (2007). Global governance of food production and consumption: Issues and challenges. Edward Elgar Publishing.

Park, J., Conca, K., \& Finger, M. (2008). The crisis of global environmental governance: Towards a new political economy of sustainability Routledge.

Parr, T. W., Sier, A. R., Battarbee, R., Mackay, A., \& Burgess, J. (2003). Detecting environmental change: Science and society-perspectives on long-term research and monitoring in the 21st century. Science of the Total Environment, 310(1), 1-8.

Pattberg, P. H. (2007). Private institutions and global governance: The new politics of environmental sustainability Edward Elgar Pub.

Pavlikakis, G. E., \& Tsihrintzis, V. A. (2000). Ecosystem management: A review of a new concept and methodology. Water Resources Management, 14(4), 257-283.

Pettenger, M. E. (Ed.). (2007). The social construction of climate change: Power knowledge norms discourses. Aldershot/Burlington: Ashgate Publishing.

Pierre, J., \& Peters, G. B. (2000). Governance, politics and the state.

Renn, O. (2008). Risk governance: Coping with uncertainty in a complex world Earthscan/James \& James.

Rhodes, R. A. (1997). Understanding governance: Policy networks, governance, reflexivity and accountability Open University Press.

Robertson, D. P., \& Hull, R. B. (2001). Beyond biology: Toward a more public ecology for conservation. Conservation Biology, 15(4), 970-979.

Roe, E., \& Van Eeten, M. (2001). Threshold-based resource management: A framework for comprehensive ecosystem management. Environmental Management, 27(2), 195-214.

Rosamund, B. (2007). New theories of european integration. In M. Cini (Ed.), European union politics (2nd ed., pp. 117). Oxford: Oxford University Press. 
Rosenau, J.N. (1999). Toward an ontology for global governance. Approaches to Global Governance Theory.Albany.NY: State University of New York,

Rosenau, J. N. (2003). Distant proximities: Dynamics beyond globalization Princeton University Press.

Rosenau, J. N., \& Czempiel, E. (1992). Governance without government: Order and change in world politics Cambridge Univ Press.

Sanwal, M. (2004). Trends in global environmental governance: The emergence of a mutual supportiveness approach to achieve sustainable development. Global Environmental Politics, 4(4), 16-22.

Sanwal, M. (2007). Evolution of global environmental governance and the united nations. Global Environmental Politics, 7(3), 1-12.

Selin, H., \& VanDeveer, S. D. (2003). Mapping institutional linkages in european air pollution politics. Global Environmental Politics, 3(3), 14-46.

Sikor, T. (Ed.). (2008). Public and private in natural resource governance: A false dichotomy?. London/Sterling: Earthscan.

Slocombe, D. S. (1998). Defining goals and criteria for ecosystem-based management. Environmental Management, 22(4), 483-493.

Speth, J. G., \& Haas, P. M. (2006). Global environmental governance. Washington DC: Island press.

Stringer, L. C., Dougill, A. J., Fraser, E., Hubacek, K., Prell, C., \& Reed, M. S. (2006). Unpacking "participation” in the adaptive management of social-ecological systems: A critical review. Ecology and Society, 11(2), 39.

Van den Hove, S. (2007). A rationale for science-policy interfaces. Futures, 39(7), 807-826.

von Malmborg, F. (2003). Conditions for regional public-private partnerships for sustainable development-Swedish perspectives. European Environment, 13(3), 133-149.

Wang, H. (2004). Ecosystem management and its application to large marine ecosystems: Science, law, and politics. Ocean Development \& International Law, 35(1), 41-74.

Wilson, D. C. (2009). The paradoxes of transparency: Science and the ecosystem approach to fisheries management in europe Amsterdam University Press.

Winter, G. (Ed.). (2006). Multilevel governance of global environmental change: Perspectives from science, sociology, and the law. Cambridge: Cambridge University Press.

Yaffee, S. L. (1999). Three faces of ecosystem management. Conservation Biology, 13(4), 713-725. 
Young, O. R. (2009). Governance for sustainable development in a world of rising interdependencies. Governance for the Environment. New Perspectives, 12-40. 